\title{
Eksplorasi Konsep Fisika pada Proses Pembuatan Anyaman Tikar Tradisional
}

\author{
Narwasti Tamelan ${ }^{1}$, Landiana Etni Laos ${ }^{2, *)}$, Infianto Boimau ${ }^{3}$ \\ Sekolah Tinggi Keguruan dan Ilmu Pendidikan Soe, Soe, Indonesia \\ narwastifisika.1993@gmail.com ${ }^{1}$, landianalaos28@gmail.com ${ }^{2}$, infiantoboimau@gmail.com ${ }^{3}$ \\ ${ }^{*}$ Corresponding author
}

Kata Kunci:

Kearifan Lokal; Konsep Fisika;

Anyaman Tikar

\begin{abstract}
ABSTRAK
Penelitian ini dilakukan pada Suku Amanatun Selatan khususnya Desa Nenoat dengan tujuan untuk mengetahui konsep-konsep fisika yang terdapat pada tahapan proses anyaman tradisional tikar. Penelitian ini menggunakan penelitian kualitatif fenomenologi dan menggunakan teknik trianggulasi berupa observasi, wawancara dan dokumentasi. Instrumen dalam penelitian ini adalah peneliti sendiri dan wawancara.Teknik analisis data yang digunakan dalam penelitian ini adalah analisis interaktif. Hasil penelitian diperoleh bahwa pada proses pembuatan tikar terdapat konsep-konsep fisika yang dieksplor seperti energi potensial, aksi reaksi, gaya, gaya gesek, tekanan, usaha, kesetimbangan, gaya berat, gaya normal, kalor, perpindahan kalor secara radiasi, gaya tarik, massa, dan percepatan.
\end{abstract}

\section{PENDAHULUAN}

Pendidikan merupakan salah satu kebutuhan pokok dalam kehidupan manusia yang harus dikembangkan dalam lingkungan setempat (Sudiatmika, 2013). Pendidikan berbasis keunggulan lokal merupakan kesadaran yang timbul dari diri sendiri dalam upaya mewujudkan suatu suasana belajar dan proses pembelajaran, agar peserta didik aktif dalam mengembangkan potensi yang ada pada dirinya sehingga memiliki keahlian, pengetahuan dan sikap dalam upaya ikut serta membangun lingkungan setempat (Prasetyo, 2013). Inovasi pendidikan merupakan suatu perubahan, ide, gagasan berupa pikiran cemerlang dari hasil olah pikir yang di terapkan melalui langkah tertentu dan dapat diyakini untuk memecahkan permasalahan dalam pendidikan yang timbul di lingkungan sekitar dan dapat memperbaiki suatu keadaan yang terjadi di masyarakat (Kusnandi, 2017).

Berdasarkan hasil observasi selama PPL di SMP Kristen 2 Soe permasalahan yang didapat bahwa peserta didik kurang memahami konsep pembelajaran fisika di kelas. Dengan adanya kurikulum 2013 maka peran guru di kelas semakin berkurang dimana guru hanya berperan sebagai fasilitator untuk mengarahkan peserta didik sedangkan peserta didik yang berperan aktif dalam proses pembelajaran. Media pembelajaran di sekolah juga masih kurang sehingga peserta didik cenderung merasa malas dan bosan karena pembelajaran hanya ada pada buku sumber yang di sediakan di sekolah, sehingga mengakibatkan peserta didik tidak mampu menguasai konsep fisika yang di pelajari. Salah satu cara yang dapat dilakukan dalam pembelajaran fisika di sekolah adalah dengan memanfaatkan budaya lokal yang ada di sekitar peserta didik. 
Agar pembelajaran ekfektif maka kearifan lokal dapat diintegrasikan dalam pembelajaran fisika sehingga peserta didik lebih mudah memahami dan memanfaatkan budaya yang ada. Kearifan lokal merupakan keberadaan suatu budaya yang perlu dikenalkan kepada generasi muda melalui dunia pendidikan karena generasi muda setempat itulah yang akan menjaga dan melestarikan daerahnya sendiri. Pendidikan berbasis potensi lokal berusaha mengaitkan materi baru dengan sistimatika yang sudah ada tentang sesuatu yang sudah biasa diketahui oleh peserta didik pada lingkungan (Bakhtiar, 2016).

Kabupaten Timor Tengah Selatan (TTS) memiliki budaya lokal yang menjadi ciri khas daerah, baik berupa makanan, upacaradat istiadat, dan berbagai tarian. Nilai kearifan dari daerah tersebut sangat kuat dan selalu menjadi kebanggaan terbesar yang kaya akan keanekaragaman seperti sumber daya yang dimiliki masyarakat tersebut berupa pembuatan putak, pembuatan $u k s a g u$, pemintalan benang, pembuatan tenun dan masih banyak kerajinan lainnya. Melihat banyaknya potensi budaya yang ada di TTS maka upaya yang akan dilakukan adalah mengajarkan peserta didik untuk melestarikan potensi budaya lokal tersebut. Hal tersebut bertujuan untuk menanamkan nilai-nilai budaya lokal kepada anak sejak dini, agar tidak terpengaruh oleh budaya luar saat ini. Pembelajaran fisika akan lebih bermanfaat jika dihubungkan dengan kearifan lokal yang ada di Kabupaten Timor Tengah Selatan (TTS) seperti pada anyaman tikar, akan tetapi hal tersebut tidak dimanfaatkan sebagai sumber belajar melainkan dipakai sebagai kerajinan budaya dan kesenian.

Kearifan lokal anyaman sudah lama digunakan oleh masyarakat setempat secara turun-temurun, bahan dasar yang digunakan dalam anyaman tersebut adalah daun lontar. Lontar merupakan tanaman lokal yang memiliki potensi sebagai sumber bioetanol. Manfaat lontar cukup banyak dan memiliki manfaat yang sangat besar. Niranya dapat dibuat minuman segar dan makanan penyegar/pencuci mulut berkalori tinggi, cuka atau kecap dan gula lontar/gula lempeng. Buahnya untuk manisan atau buah kalengan, kue, selai dan obat kulit (dermatiti). Bunganya untuk obat sakit lever dan daunnya dapat dimanfaatkan untuk bahan kerajinan tangan berupa anyaman (Nasri et al., 2017). Selain menganyam lontar juga dapat dimanfaatkan sebagai perabot rumah tangga seperti alat penapi, ketupat, tikar, kipas api, tempat sirih pinang (oko mama), tempat penyimpanan beras ( $\mathrm{Ta}{ }^{\prime} \mathrm{ka}$ ), tutupan saji (Tobe) dan ada juga manfaat lain dari daun lontar seperti tarian giring-giring (telsain) dan masih banyak lainnya.

Tikar merupakan bahan lokal yang berasal dari daun lontar di masyarakat TTS terutama suku Amanatun Selatan, tikar dimanfaatkan sebagai tempat mengadakan ritual adat, selain itu juga tikar memiliki nilai jual yang tinggi sehingga masyarakat Amanatun selatan memanfaatkan tikar untuk dijual dengan tujuan memenuhi kebutuhan ekonomi mereka. Oleh karena itu, penulis tertarik untuk meneliti konsep fisika apa yang ada pada proses pembuatan tikar. Berdasarkan latar belakang yang telah diuraikan, yang menjadi fokus dalam penelitian ini adalah untuk mengidentifikasi konsep fisika pada proses pembuatan tikar pada masyarakat Amanatun Selatan, Desa Nenoat, Kecamatan Nunkolo, Kabupaten TTS.

\section{METODE PENELITIAN}

Jenis penelitian ini adalah penelitian kualitatif fenomenologi. Penelitian fenomenologi dapat dimulai dengan melihat dan menelaah suatu fenomena yang ada pada proses anyaman tikar. Peneliti melakukan penggalian data pada tahapan anyaman tikar sehingga dapat menemukan arti pada fenomena tersebut. Penggalian data dengan cara wawancara mendalam, observasi langsung dan dokumentasi pada tahapan pembuatan tikar. Data yang diperoleh dianalisis terus menerus sampai selesai jika tidak ada data lain lagi maka data tersebut sudah jenuh. Aktivitas dalam analisis tersebut meliputi reduksi data (data reduction), setelah data direduksi tahap selanjutnya adalah penyajian data (data display) merupakan aktivitas yang dilakukan oleh peneliti. Tahap terakhir yang dilakukan adalah penarikan kesimpulan yang didasarkan pada budaya masyarakat Amanatun Selatan, Desa Nenoat yang telah dieksplor kedalam konsep-konsep fisika yang diperoleh peneliti dari lapangan.

Teknik pengumpulan data menggunakan teknik triangulasi yang terdiri dari observasi, wawancara dan dokumentasi. Penelitian ini dilakukan pada masyarakat suku Amanatun selatan khususnya, Desa 
Nenoat, Kecamatan Nunkolo. Instrumen dalam penelitian ini peneliti sendiri dan wawancara. Sumber data dalam penelitian ini adalah data primer dan sekunder. Data primer berarti data tersebut diperoleh langsung dari sumbernya bukan dari sumber lain. Sedangkan data sekunder berarti data tersebut diperoleh dari sumber lain seperti buku, dokumen, artikel dan lain sebagainya.

Proses analisis data dalam penelitian ini dilakukan secara terus menerus sejak awal sampai akhir penelitian. Teknik analisis data yang digunakan dalam penelitian ini adalah analisis interaktif. Untuk menilai keabsahan data apakah data tersebut valid, maka peneliti perlu melakukan pemeriksaan secara cermat dan teliti karena hanya data-data yang valid dapat diteliti. Kevalidan suatu data dilihat dari substansi, sumber data, maupun teknik pengambilan datanya.

\section{HASIL DAN PEMBAHASAN}

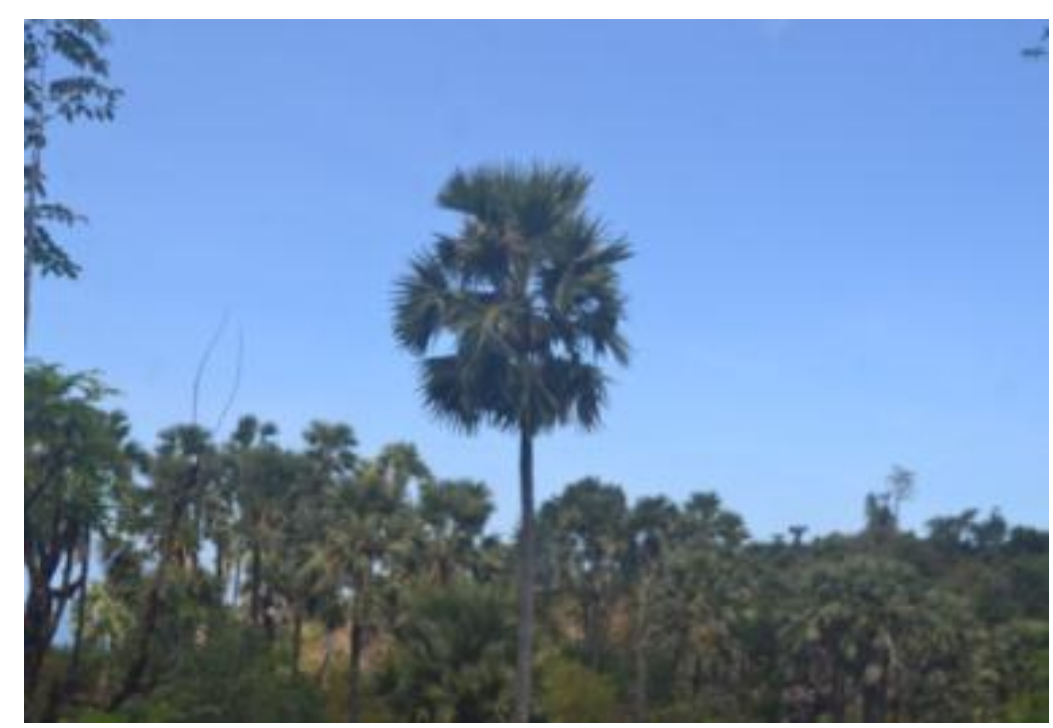

Gambar 1. Tumbuhan Lontar

Lontar (Gambar 1) merupakan tanaman lokal yang memiliki potensi sebagai sumber bioetanol. Manfaat lontar cukup banyak dan memiliki manfaat yang sangat besar. Kebanyakan lontar tumbuh di wilayah terpencil seperti pedesaan, pada masyarakat Timor Tengah Selatan (TTS) khususnya suku Amanatun Selatan menyebut tumbuhan lontar dengan sebutan Noe/Tua. Tumbuhan lontar memiliki banyak manfaat dan banyak dikenal oleh masyarakat Indonesia, karena terbukti manfaat dan kegunaannya. Daunnya dapat dimanfaatkan untuk bahan kerajinan tangan berupa anyaman sebagai perabot rumah tangga seperti alat penapi, ketupat, tikar, kipas api, tempat sirih pinang (oko mama), tempat penyimpanan beras ( $\left.T a^{\prime} k a\right)$, tutupan saji (Tobe) dan ada juga manfaat lain dari daun lontar seperti tarian giring-giring (telsain) masih banyak lagi kerajinan lainnya. Buah lontar untuk manisan, bisa dimakan atau buah kalengan, kue, selai dan obat kulit (dermatiti) dan juga niranya bisa dipakai untuk membuat gula merah juga sangat bermanfaat bagi kesehatan. Niranya dapat dibuat minuman segar dan makanan penyegar/pencuci mulut berkalori tinggi, cuka atau kecap, gula lempeng dan bunganya untuk obat sakit lever. Tumbuhan lontar memiliki batang pohon yang tinggi sekitar lima hingga 20 meter. Pohon lontar memiliki garis-garis horizontal atau melintang di batangnya, garisnya renggang dan tebal memiliki buah kecil, berbentuk bulat dan memiliki warna yang hitam kekuningan, memiliki daun diujung tangkainya yang melebar berbentuk seperti kipas.

Pembuatan tikar terdiri atas beberapa langkah, setiap langkah mengandung resiko yang pertama pada proses pengambilan daun harus memanjat terlebih dahulu untuk mengambil daunnya. Bahan yang dibutuhkan untuk pengambilan daun lontar yaitu barang tajam untuk memotong berupa parang. Setelah daun di ambil langkah selanjutnya adalah pisahkan daun dari tangkainya selanjutnya adalah proses setelah itu tahap pengeringannya dengan cara daun lontar di jemur di bawah terik matahari jangan terlalu lama sehingga tidak terlalu kering karena jika terlalu kering maka daun tersebut akan 
terasa kaku dan lebih cepat putus jika daun terlalu kering maka daun tersebut dapat di rendam kedalam air sehingga kembali lembab pada penjemuran membutuhkan waktu setengah hari. Setelah proses pengeringan maka langkah selanjutnya adalah memisahkan lidi dengan daunnya, langkah selanjutnya adalah proses penganyaman tikar (tanaon nahe).

Anyaman merupakan bahan serat yang di rangkai dari bahan yang berasal dari tumbuhan seperti dari daun lontar yang digunakan untuk menganyam tikar. Langkah pertama menganyam adalah irisan daun lontar disusun secara melintang sehingga setiap irisan daun lontar harus tersusun atas dua irisan daun sehingga mudah dibentuk, pada bagian ujung irisan daun lontar dibuat runcing supaya dapat masuk pada anyaman yang lain jika ujungnya tidak dibuat runcing maka sangat sulit untuk melapisi anyaman yang masih memiliki celah. Saat menganyam tikar maka harus memulai anyamannya dari samping kiri ke kanan untuk menganyam tikar membutuhkan waktu 3 atau 4 hari. Waktu menganyam dipagi dan sore hari karena pada siang hari maka daun tersebut akan terasa kaku dan mengeras karena pengaruh suhu di siang hari lebih panas dari pagi hari dan sore hari. Dalam anyaman alat yang dibutuhkan adalah kayu yang di runcing kecil, kayu tersebut digunakan membuat celah agar dapat melapisi daun pada anyaman. Eksplorasi konsep-konsep fisika pada proses pembuatan anyaman tikar tradisional pada budaya masyarakat Amanatun Selatan Desa Nenoat, Kecamatan Nunkolo, Kabupaten Timor Tengah Selatan dapat dilihat pada Tabel 1.

Tabel 1. Eksplorasi Konsep-Konsep Fisika pada Proses Pembuatan Anyaman Tikar Tradisional

\begin{tabular}{|c|c|c|c|c|}
\hline $\begin{array}{l}\mathbf{N} \\
\mathbf{0}\end{array}$ & Tahapan & Fenomena & Penjelasan & Konsep Fisika \\
\hline 1 & Memanjat & hon Lo & $\begin{array}{l}\text { adalah berusaha untuk } \\
\text { ketinggian suatu benda } \\
\text { es inisi pemanjat ingin } \\
\text { il daun lontar yaitu } \\
\text { ara memanjat sampai } \\
\text {. Ada energi potensial } \\
\text { au dari ketinggian pohon } \\
\text { Energi potensial } \\
\text { energi yang dimiliki } \\
\text { benda karena letak atau } \\
\text { nnya. Adapun massa } \\
\text { otot yang dimiliki si }\end{array}$ & $\begin{array}{l}\text { Energi potensial } \\
\mathbf{E p}=\mathbf{m g h} \\
\text { Massa } \\
\mathbf{W}=\mathbf{m} \times \mathbf{g} \\
\text { Gaya otot }\end{array}$ \\
\hline & Memotong & dan? & $\begin{array}{l}\text { g adalah memisahkan } \\
\text { lenggunakan alat tajam } \\
\text { ses ini adalah si bapak } \\
\text { rusaha untuk mengambil } \\
\text { ar dengan menggunakan } \\
\text { caranya tangan si bapak } \\
\text { ke atas dengan } \\
\text { gaya dan tekanan. } \\
\text { besar tekanan yang } \\
\text { maka semakin kecil } \\
\text { k. }\end{array}$ & $\begin{array}{l}\text { Gaya } \mathbf{F}=\mathbf{m} \times \mathbf{a} \\
\text { Gaya gesek } \\
\mathbf{f}=\boldsymbol{\mu} \mathbf{x} \mathbf{N} \\
\text { Tekanan } \\
\mathbf{P}=\frac{F}{A}\end{array}$ \\
\hline
\end{tabular}




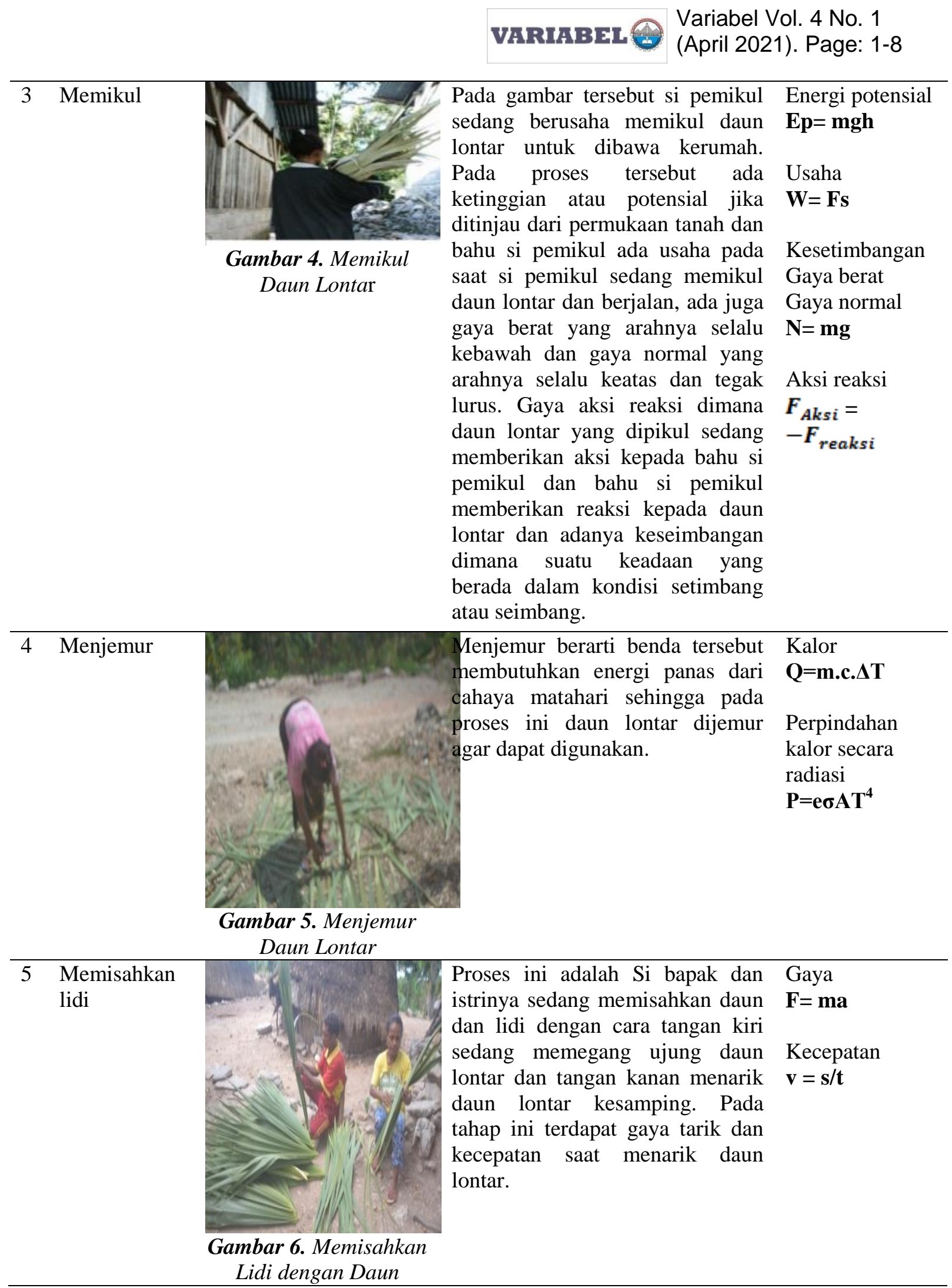




\begin{tabular}{|c|c|c|c|c|}
\hline & Merapikan & $\begin{array}{c}\text { Gambar 7. Sayat Daun } \\
\text { Lontar }\end{array}$ & $\begin{array}{l}\text { Merapikan daun lontar dengan } \\
\text { cara disayat terdapat gaya gesek } \\
\text { antara pisau dan daun lontar. Ada } \\
\text { juga percepatan yaitu ketika gerak } \\
\text { pisau berbading lurus dengan } \\
\text { gaya yang diberikan dan tekanan } \\
\text { saat si ibu sedang menekan pisau } \\
\text { sehingga arahnya mengikuti } \\
\text { sayatan tersebut. }\end{array}$ & $\begin{array}{l}\text { Gaya } \\
\mathbf{F}=\mathbf{m} \times \mathbf{a} \\
\text { Gaya gesek } \\
\mathbf{f}=\boldsymbol{\mu} \mathbf{x} \mathbf{N} \\
\text { Tekanan } \\
\mathbf{P}=\frac{F}{A} \\
\text { Percepatan } \\
\mathbf{a}=\mathbf{v} / \mathbf{t}\end{array}$ \\
\hline 7 & Menganyam & Gambar 8. Menganyam & $\begin{array}{l}\text { Menganyam merupakan karya } \\
\text { seseorang. Pada gambar } \\
\text { disamping menunjukan bahwa si } \\
\text { ibu sedang menganyam tikar. } \\
\text { Ketika si ibu sedang menarik } \\
\text { irisan daun lontar maka terdapat } \\
\text { gaya gesek. Disebut gaya gesek } \\
\text { karena sebuah benda yang } \\
\text { memberikan gaya harus } \\
\text { menyentuh benda lain yang } \\
\text { dikenai gaya tersebut atau pada saat } \\
\text { tangan si ibu yang sedang } \\
\text { memegang daun lontar maka ada } \\
\text { gesekan langsung dari permukaan } \\
\text { lontar dengan tangan Ibu. }\end{array}$ & $\begin{array}{l}\text { Gaya gesek } \\
\mathbf{f}=\boldsymbol{\mu} \mathbf{x} \mathbf{N} \\
\text { Gaya tarik } \\
\mathbf{F}=\mathbf{m a}\end{array}$ \\
\hline
\end{tabular}

Berdasarkan hasil proses anyaman tikar dan hubunganya dengan konsep-konsep fisika, ketika di diintegrasikan dalam pembelajaran fisika disesuaikan dengan kompetensi dasar yang disajikan pada Tabel 2 dan 3.

Tabel 2. Hubungan antara tahapan anyaman tikar dengan Kompetensi Dasar Fisika di SMP.

\begin{tabular}{|c|c|c|}
\hline No & Kompetensi Dasar & $\begin{array}{l}\text { Konsep fisika dalam proses anyaman } \\
\text { tikar }\end{array}$ \\
\hline 1 & $\begin{array}{l}\text { Mendeskripsikan peran kalor dalam mengubah } \\
\text { wujud zat dan suhu suatu benda serta } \\
\text { penerapannya dalam kehidupan sehari-hari. }\end{array}$ & $\begin{array}{l}\text { Pada proses penjemuran terjadi perpindahan } \\
\text { kalor secara radiasi sehingga dapat } \\
\text { mengeringkan daun lontar }\end{array}$ \\
\hline 2 & $\begin{array}{l}\text { Memahami peranan usaha, gaya dan tekanan } \\
\text { dalam kehidupan sehari-hari. }\end{array}$ & $\begin{array}{l}\text { Pada proses tersebut ada usaha, gaya dan } \\
\text { tekanan yang dibutuhkan }\end{array}$ \\
\hline
\end{tabular}

Tikar merupakan kerajinan tangan berupa anyaman berbahan lokal dari tumbuhan alam yaitu lontar yang tumbuhnya di daerah beriklim tropis atau daerah pantai. Lontar atau biasanya dikenal dengan sebutan tuak di daerah Timor Tengah Selatan, buahnya dapat dimakan dan dijadikan manisan dan niranya dapat diminum atau dapat digunakan untuk memasak gula merah sedangkan daunnya dapat digunakan untuk berbagai kesenian berupa tikar, keranjang, topi, dan lain sebagainya. Nasri et al., (2017) berpendapat bahwa selain menganyam daun lontar juga dapat dimanfaatkan sebagai kertas untuk menulis naskah, surat dan dokumen-dokumen kerajaan pada zaman nenek moyang. Anyaman merupakan kerajinan tangan yang memiliki teknik dalam menganyam yaitu dengan cara mengatur bahan dasarnya dalam bentuk menindih (memberikan tekanan), menyilang, melipat dan memasukan daun ke celah yang ada (Yulika et al., 2017). 
Tabel 3. Hubungan antara tahapan anyaman tikar dengan Kompetensi Dasar Fisika di SMA.

\begin{tabular}{|c|c|c|}
\hline No & Kompetensi Dasar & $\begin{array}{c}\text { Konsep fisika dalam tahapan pada } \\
\text { anyaman tikar }\end{array}$ \\
\hline 1 & $\begin{array}{l}\text { Menerapkan hukum Newton untuk } \\
\text { menjelaskan beberapa peristiwa dalam } \\
\text { kehidupan sehari-hari }\end{array}$ & $\begin{array}{l}\text { Adanya energi potensial pada saat } \\
\text { memanjat untuk mengambil daun lontar dan } \\
\text { ditinjau dari ketinggian. }\end{array}$ \\
\hline 2 & $\begin{array}{l}\text { Menganalisis data percobaan gerak lurus } \\
\text { beraturan dan gerak lurus berubah beraturan } \\
\text { serta penerapannya dalam kehidupan sehari- } \\
\text { hari. }\end{array}$ & $\begin{array}{l}\text { Adanya percepatan pada saat menyayat } \\
\text { daun lontar }\end{array}$ \\
\hline 3 & $\begin{array}{l}\text { Menerapkan konsep torsi, momen inersia, titik } \\
\text { berat dan momentum sudut pada benda tegar } \\
\text { (statis dan dinamis) dalam kehidupan sehari- } \\
\text { hari. }\end{array}$ & $\begin{array}{l}\text { Adanya keseimbangan, gaya berat, gaya } \\
\text { normal, aksi reaksi pada saat memikul daun } \\
\text { lontar }\end{array}$ \\
\hline
\end{tabular}

Kebudayaan dapat membawa pengaruh yang bersifat langsung dari lingkungan sosial dimana seseorang dengan kebiasaannya menjalaninya sebagai proses, pengetahuan yang terkait dengan kehidupan di lingkungannya baik yang belum terwujud maupun yang telah terwujud sehingga ada dorongan untuk belajar dan melestarikan lingkungan sekitar (Thamrin, 2013). Adapun konsep fisika yang ada dalam tahap pembuatan tikar yang berbasis kearifan lokal dapat diintegrasikan dalam pembelajaran fisika.

Masyarakat di Desa Nenoat masih mempertahankan budaya pembuatan tikar dengan alasan bahwa pembuatan tikar ini sudah diwariskan turun temurun sampai saat ini. Alasan yang lain karena pembuatan tikar dapat dimanfaatkan sebagai proses menafkahi keluarga mereka secara ekonomi dari dulu sampai sekarang. Sebagai makhluk berbudaya dalam memenuhi kebutuhan hidup mereka berusaha untuk mengolah segala sesuatu yang tersedia di alam sekitarnya sesuai dengan kemampuan yang mereka miliki. Kemampuan tersebut menyangkut tiga unsur pokok budaya mereka sebagai kebulatan, yaitu pikiran atau cipta, kemauan atau karsa dan rasa.Walaupun hampir punah atau hilang tetapi sebagian dari masyarakat tersebut masih mempertahankan kegiatan tersebut sebagai rutinitas mereka. Proses pembuatan tikar ini dieksplor kembali untuk dihubungkan dengan pembelajaran fisika. Terdapat banyak konsep fisika pada proses pembuatan tikar mencerminkan bahwa budaya lokal masyarakat dapat dijadikan sumber belajar fisika yang memberikan pengalaman langsung kepada peserta didik sehingga mereka dapat memahami alam sekitar secara ilmiah. Peserta didik mampu mempelajari gejala-gejala alam yang tidak terbatas, sehingga peserta didik dapat membangun konsep fisika dan memecahkan masalah dalam kehidupan sehari-hari.

Parmin (2015) menegaskan bahwa jika perhatian terhadap suatu keadaan sebagai titik awal sebuah proses maka ada hubungan yang kuat antara tindakan seseorang ketika sedang berinteraksi dengan lingkungan sekitar. Sehingga pada keadaan tersebut sangat mendukung proses pembelajaran dan pandangan peserta didik terhadap alam sekitar. Sehingga dalam pembelajaran fisika guru harus mampu mengaitkan materi fisika dengan berbagai fenomena yang sering dijumpai oleh peserta didik di lingkungan sekitarnya.

\section{KESIMPULAN}

Berdasarkan penelitian yang dilakukan maka dapat disimpulkan bahwa terdapat konsep fisika pada proses pembuatan tikar pada masyarakat Amanatun Selatan Desa Nenoat. Konsep-konsep fisika yang diemukan pada proses pembuatan tikar yaitu energi potensial, aksi reaksi, gaya, gaya gesek, tekanan, usaha, kesetimbangan, gaya berat, gaya normal, kalor, perpindahan kalor secara radiasi, gaya tarik, dan percepatan.

Berdasarkan hasil penelitian maka saran penulis sebagai berikut: (1) pengambilan data dan pembahasan konsep fisika masih dilakukan penulis sendiri dan belum diterapkan dalam pembelajaran 
di sekolah. (2) Penelitian ini hanya dilakukan untuk menemukan konsep fisika secara umum yang ada pada tahap-tahap pembuatan tikar maka untuk kebutuhan penelitian selanjutnya bagi yang berminat meneliti mengenai kebudayaan salah satunya anyaman tikar dan dapat mengelompokan beberapa materi yang sesuai dengan jenjang tingkat sekolah dan membahasnya secara lebih mendalam.

\section{DAFTAR PUSTAKA}

Bakhtiar. (2016). Bahan Ajar Berbasis Kearifan Lokal Terintegrasi STM (Sains, Teknologi Dan Masyarakat) Pada Mata Pelajaran Fisika. Prosiding Seminar Nasional Pendidikan. Universitas Jamber.

Kusnandi. (2017). Model Inovasi Pendidikan dengan Strategi Implementasi Konsep "Dare To Be Different". Wahana Pendidikan, 4(1).

Nasril, Suryaningsih. \& Kurniawan, E. (2017). Ekologi, Pemanfaatan dan Sosial Budaya Lontar (Borassus Flabellifer Linn) Sebagai Flora Identitas Sulawesi Selatan. Prosiding Ekologi, Pemanfaatan dan Sosial Budaya Lontar, 4(1), 35-46.

Parmin. (2015). Potensi Kearifan Lokal dalam Pembelajaran IPA di SMP.Prosiding Seminar nasional Konservasi dan Pemanfaatan Sumber Daya Alam.

Prasetyo, Z. K. (2013). Pembelajaran Sains Berbasis Kearifan Lokal. Prosiding: Seminar Nasional Fisika dan Pendidikan Fisika.

Sudiatmika. (2013). Pendidikan Sains Berlandaskan Budaya Lokal Tri Kaya Parisudha. Prosiding Seminar Nasional Fisika. Surakarta: FKIP UNS Fisika.

Thamrin. (2013). Kearifan Lokal dalam Pelestarian Lingkungan (The Lokal Wisdom In Environmental Sustainable).

Yulika. F., Yulimarni., \& Rahmanita, N ( 2017). Ulakan Tapakis melalui Pengembangan Desain Produk Anyaman Pandan. Jurnal Batoboh, 2(2). 